\title{
Conclusion: Becoming Ourselves
}

For a very long time, Matsu sat on the edge of an empire, an outlying archipelago beyond the reach of state power. During a period of limited resources, people came and went, using the islands as a temporary shelter. In 1949, however, the happenstance of history transformed these isolated mountainous islands into a frontline: the occupation of the Nationalist army marked the start of more than forty years of strict military rule. The army carried out large-scale construction projects and provided new opportunities for education, but it also created many conflicts and traumas. As the US-Soviet Cold War came to an end, tensions across the Taiwan Strait loosened, and martial law was eventually lifted in 1992. After Matsu lost its military and tactical usefulness, its people were confronted with the existential question of who they were, and how to redefine themselves and their place in the world. Above all, how could the islands move forward so as to surmount their previous fate as either an ignored outpost on the periphery of the state, or a subjugated area under the strictures of military control? This book has discussed how the islands' middle-aged generation, who were sent to Taiwan to study during the wartime period, have devised a series of new imaginaries, or blueprints, for Matsu's future development. They grew up suffering the adversities of military rule, and after living and studying in Taiwan or in the world at large, they resynthesized their own experiences and knowledge and returned home with new ideas and inspiration. With diverse abilities, values, and beliefs, they built their individual imaginations of the islands and developed them through varied mediating mechanisms - including new media technologies, novel religious practices, and neoliberal economic concepts-in order to rescale and 
reposition Matsu in the world. We have seen how different imaginations were given an unprecedented chance to develop during this critical moment of uncertainty. The rich ethnography of these consecutive imaginaries of Matsu provide an unusual case for studying how the individual imagination can transform into a social imaginary.

As Anderson (1991[1983]) and Appadurai (1996) have shown with great foresight, print-capitalism and mass media have historically enabled national and global imaginings. This book goes one step further to analyze how imagining subjects can deploy new mediating technologies to explore their imaginations and extend them into the wider community; in other words, how individual imaginations can turn into social imaginaries. As an isolated archipelago in its early days, and as a military frontline for a significant stretch of the twentieth century, the imaginations of the Matsu individuals were less visible or simply hidden. It was only when the barriers were lifted, and the islands were no longer cut off from the world, that their imaginations had more opportunities to flourish and began to disseminate quickly.

Having experienced the longstanding oppression of military rule, how could individuals become imagining subjects? How could subjectification occur? And in what ways could the individual imagination reach the collective? Military rule undeniably left scars of varying severity on everyone living in Matsu at the time, but the military's withdrawal left the former frontline islands alone in the enormous ocean, facing a precarious future on their own. This book illustrates how the people of Matsu applied new imaginative technologies, invented rituals and myths, and even drew on the gaming industry in concerted attempts to relocate Matsu within different regional and global frameworks in order to find new possibilities for themselves. It importantly highlights that the serial island imaginaries that they evolved are also processes of subjectification. That is, social imaginary usually starts with individuals' reflections and combines their particular visions of the future. It then extends and spreads via different kinds of mediums and gradually coalesces a common understanding that motivates people to take concrete action. The imagining subject in previous literature has received less attention (Crapazano 2004: 1); in this book it is given primacy so as to better understand the key role it plays in contemporary society. Not all 
individual imaginations can develop into social imaginaries, owing to various social, cultural, and political factors. However, imagining subjects do not easily fade away; they remain latent and may take on renewed power at unexpected moments. This is important for understanding, in particular, the trajectory of the demilitarized islands after the Cold War.

The stories recounted in Part III of this book are still ongoing. On July 15,2011 , to commemorate the sixtieth anniversary of the first landing on Liang Island, the Matsu station troops sponsored a ceremonial trip called "Glorious Return of Heroes to the Island." During the event, the county commissioner Yang Suisheng happened to discover traces of a shell midden on the island. He invited archeologists to carry out an excavation, and they unearthed the skeletons of two people. Using carbon dating (AmsC14), they determined that the remains dated to sometime between 8,200 and 7,500 BCE, and named the bodies the "Liang Islanders" (liangdao ren). The Liang Islanders are not only the oldest Neolithic Age human skeletons ever to be found in the Min River basin area, they are also the oldest skeletons found in the Austronesian area of Taiwan. DNA analysis from 2013 further showed that the Liang Islanders' matrilineal line was most closely connected to the Austronesian lineage in Taiwan and the Philippines (C. Chen 2013).

The discovery of the Liang Islanders rekindled commissioner Yang's aspirations to connect Matsu with China across the Strait, after his plans for a gaming industry stalled. He visited the shell mound in Pingtan, Fujian in order to seek out opportunities to cooperate in archeological missions (Q. Liu 2013), and he held meetings at the Fujian Cultural Center and museum in an attempt to initiate communication and collaboration. He has also fervently participated in the One Belt, One Road initiative in China. For example, at the "21st Century Maritime Silk Road" high-level forum Yang boldly connected the archeological discovery in Matsu and its relationship to the mainland by placing Matsu along the maritime Silk Road:

Matsu is just beyond the estuary of the Min river. ...It is a pearl along the maritime Silk Road. ...I hope that we can join with Fuzhou to head down the maritime Silk Road together, toward the world and the ocean. (D. Xie 2014) 
The close linkage between the DNA of the Liang Islanders and the Austronesians gave Yang another new imaginary with which to attempt to push Matsu out "into the world." He wrote in Matsu Daily: "The Liang Islanders do not belong only to Matsu; they belong to the rest of the world even more." ${ }^{1} \mathrm{He}$ co-organized an international conference with Academia Sinica in Taipei, called "From Matsu to the Southeast Coast of Asia," in 2014 and invited well-known archeologists from around the world. After the conference, he invited academics and reporters, along with ambassadors from Kiribati, Tuvalu, and other Austronesian countries, to travel to Liang Island to advocate for its importance. In his county commissioner office bulletin, he said:

The discovery of the Liang Islanders will turn Matsu into a new point of origin for the Austronesian people, uniting the two sides of the Strait as we head out toward the greater world, turning "the pearl of Eastern Fujian" into "the world's Liang Island."

Obviously, Yang's thoughts have become increasingly "rhizomorphic," ramifying connections in all directions. Despite all his efforts, however, the Liang Islanders inspired little enthusiasm among Matsu people. Even on Matsu Online, netizens have barely followed the findings. They doubted whether the putative connection between Matsu and Austronesia could bring any economic benefits; but the largest barrier to an enthusiastic response from the islanders was that the proposal that Matsu is the origin of the Austronesian people had little resonance among the residents (Xiong 2012). Since people saw no resemblance between Austronesian history and what they understood about themselves, the potential for the development of an imagination was rather restricted.

However, given that the individual imagination frequently comes from subjective experience and an individuated interpretative process (Rapport 2015: 8), it will not simply dissolve even when it does not develop into a social imaginary. For example, after Yang failed in his reelection bid as county commissioner and left public office, he quickly pulled himself together to start building his own "trimaran," his quixotic solution to the difficulties of traversing the Taiwan Strait (Fig. C.1).

This boat is without a doubt his bid to reset himself and strike out towards a new future. Its hull was fabricated from fiber-reinforced plastic 


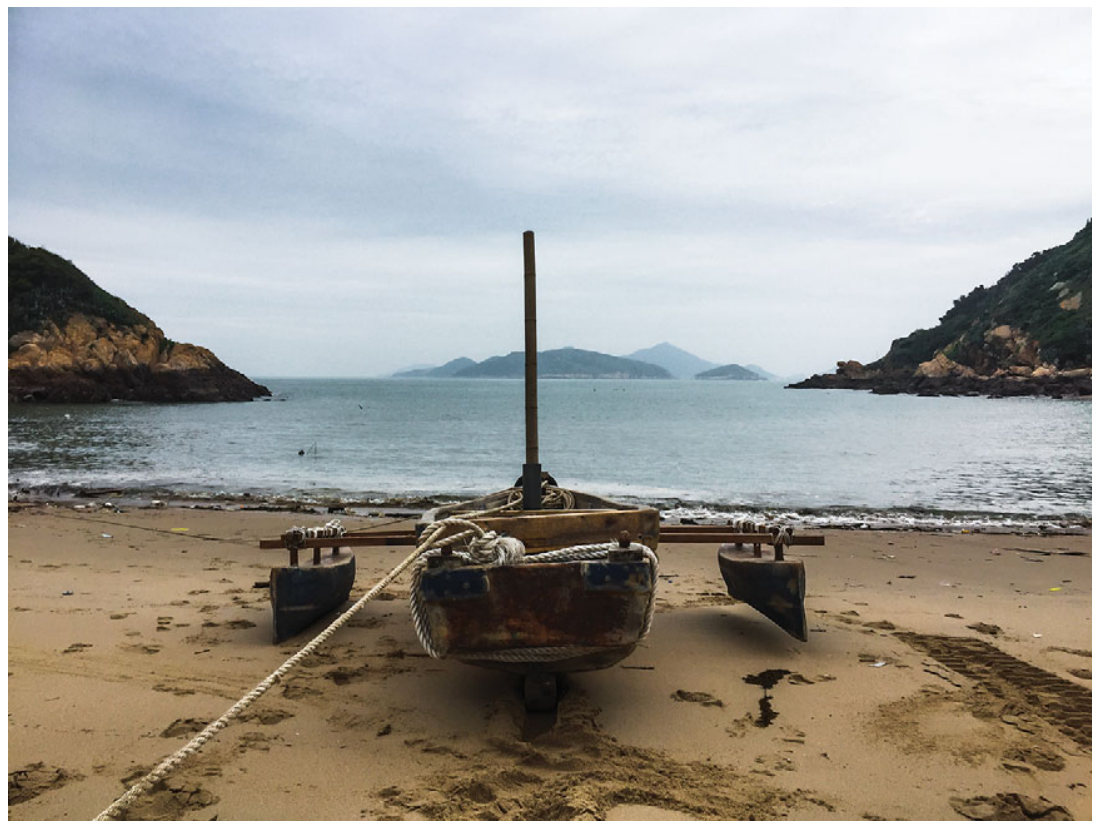

Fig. C.1 Yang Suisheng's handcrafted "Trimaran" (Photo by Yang Suisheng)

and the outriggers made from used chlorine containers (such containers are discarded by waterworks after use in the disinfecting process), a demonstration of his long-term commitment to environmental protection. Vests designed during his reelection campaign were sewn together to make the sail, the message on which reads: "Pearl of Eastern Fujian, the World's Liang Island" (mindong zhizhu, shijie liangdao). Another motivation behind the sail, as he explained, was to commemorate his great-grandmother, whom he never met. As a sailmaker, it is said that her craftsmanship was exquisite; she had even made sails for the well-known "pirate" of early twentieth-century Matsu, Lin Yihe (Chapter 1). The completion of the boat demonstrates Yang's knowledge and competence developed from many years of research on sea vessels and the ocean itself. He intends to sail the ship from Nangan to the Liang Islands, and has even designed plans to turn it into an airborne sea-craft, dreaming that his boat will one day be able to fly. When that happens, the people of Matsu will no longer have to endure arduous travel to Taiwan. 
A similar case is that of Cao Yixiong, who first proposed the Community Building Project in Matsu (Chapter 8); his dream of turning Matsu into an "Eastern Fujian Culture Village" was put into practice, but it proved to be largely unworkable. He then reconciled himself to the temple building project, even though it was not part of his original plan or interest. Along the way, he also went from being a member of the legislature to the chairmanship of the Cultural Bureau (he was appointed by Yang Suisheng). Following Commissioner Yang's failed bid for reelection, however, Cao reluctantly left office and asked himself what he should do with the rest of his life. Opportunely, the army on Matsu had recently disengaged from more than one hundred military fortresses and installations and had turned them over to the county government. Cao thought that he might apply for permission to "reutilize unused space" at Military Base No. 12 near Ox Horn, and thereby persist in his goal of preserving and revitalizing old dwellings. It was a very ambitious plan, however; now that he had no access to government resources, how would he manage to convert a military base? In the midst of his indecision, he remembered his itinerant days as a young man in Taiwan, and the novels with which he had whiled away his time. He recalled in particular one of the moving stories told in The Thorn Birds:

There is a legend about a bird which sings just once in its life, more sweetly than any other creature on the face of the earth. From the moment it leaves the nest it searches for a thorn tree, and does not rest until it has found one. Then, singing among the savage branches, it impales itself upon the longest, sharpest spine. And, dying, it rises above its own agony to out-carol the lark and the nightingale. One superlative song, existence the price. But the whole world stills to listen, and God in His heaven smiles. For the best is only bought at the cost of great pain...Or so says the legend. (Colleen McCullough 1977)

He told himself that in the latter stage of his life, he should find a tree and sing out his last beautiful song, just like the thorn birds in the book. In that way, he would be able to demonstrate his own worth. He named the abandoned military site "The Thorn Bird" (ciniao) and has since expended great effort to renovate it singlehandedly, declining every offer of help and finally even moving there himself to live (Fig. C.2).

Today he runs a bed-and-breakfast at the site. Under his careful management, it has not only become a popular scenic spot in Matsu, 


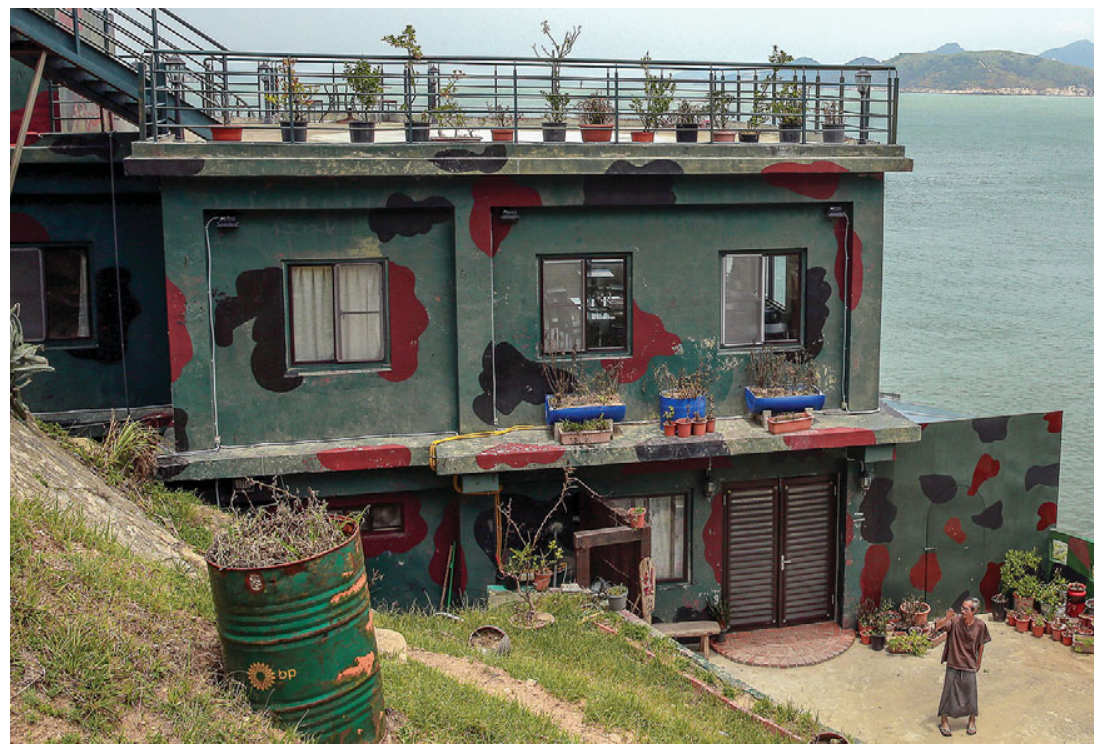

Fig. C.2 Cao Yixong at the renovated military base (Photo by Chen Junwei)

but also the site of many art events. Now, he cuts a figure quite unlike a typical government functionary: darkly tanned, lean, and dressed, sometimes eccentrically, for his own pleasure. When he was first elected to the legislature, he always put on formal Western suits, but as he started to promote community building, he began to wear more culturally significant traditional Chinese dress, and now often wears a comfortable sarong. We may say that what he is doing now “...is an obstinate search for a style of existence, a way of being" (Moore 2011: 2). He has steadfastly continued to pursue and reveal his unique self; his selfstylization extends to every tree and bush in his own seaside corner.

Finally, what happened to Cao Yaping, who came to prominence during the public debates over the gaming referendum? Although her side in the referendum failed, Cao Yaping seems more disturbed by the fact that at the time she did not have a good grasp of the military history of Matsu and so was unable to understand the views of the older generation. When she returned to school in Taiwan to finish her Master's 
degree, she chose to research the fishing economy of Matsu during the wartime era in an attempt to come to terms with the island's history. After graduating, she came back to Matsu to work. In her webzine, she writes about her experiences in Matsu-she records her daily life, or interviews with people. For example, in an article called "The history of my family business," she records how her parents ran a shop catering to soldiers during military rule. She is looking for ways to understand Matsu and to reconnect with it.

Many other post-martial-law youngsters have similar confusion about themselves and their place in the world. With Cao, they formed the "Development Association of Matsu Youth" (Matsu qingnian fazhan xiehui) after the referendum. They gather together regularly to read and discuss, and they have started to participate actively in public affairs. In 2017, several people at the fisherman's association meeting suggested relaxing certain restrictions on fishing boats that hire Chinese workers, allowing them to spread nets beyond 300 meters from the islands' coasts (down from an earlier limit of 1,000 meters). Realizing that most of these boats were actually financed by Chinese investors rather than by locals, Cao Yaping and the Youth Association launched a vigorous "Defend Matsu's Ocean" movement. Thanks to their efficiency and finesse in internet advocacy, more than 2,000 online and paper signatures (out of 6,000 long-term residents) were collected within three days, thus preventing the motion from going forward and conserving the coastal resources.

Over the past few years, the group has continuously sought a place that could serve as a "base" (jidi) from which to develop their Association. Recently, they found a long-abandoned building which used to be an elementary school during the WZA. It occupies a mere 18 ping (640 square feet) and was originally a branch of the main school intended for first through third graders in Zhuluo. Yet the school does offer something special: the basement is an air raid shelter, where Zhuluo villagers hid from bombs during the military period. The Youth Association members felt that the space holds a special significance, and that it could connect them directly to the era of martial law. After persistent efforts, they finally got permission from the government and local villagers to use 


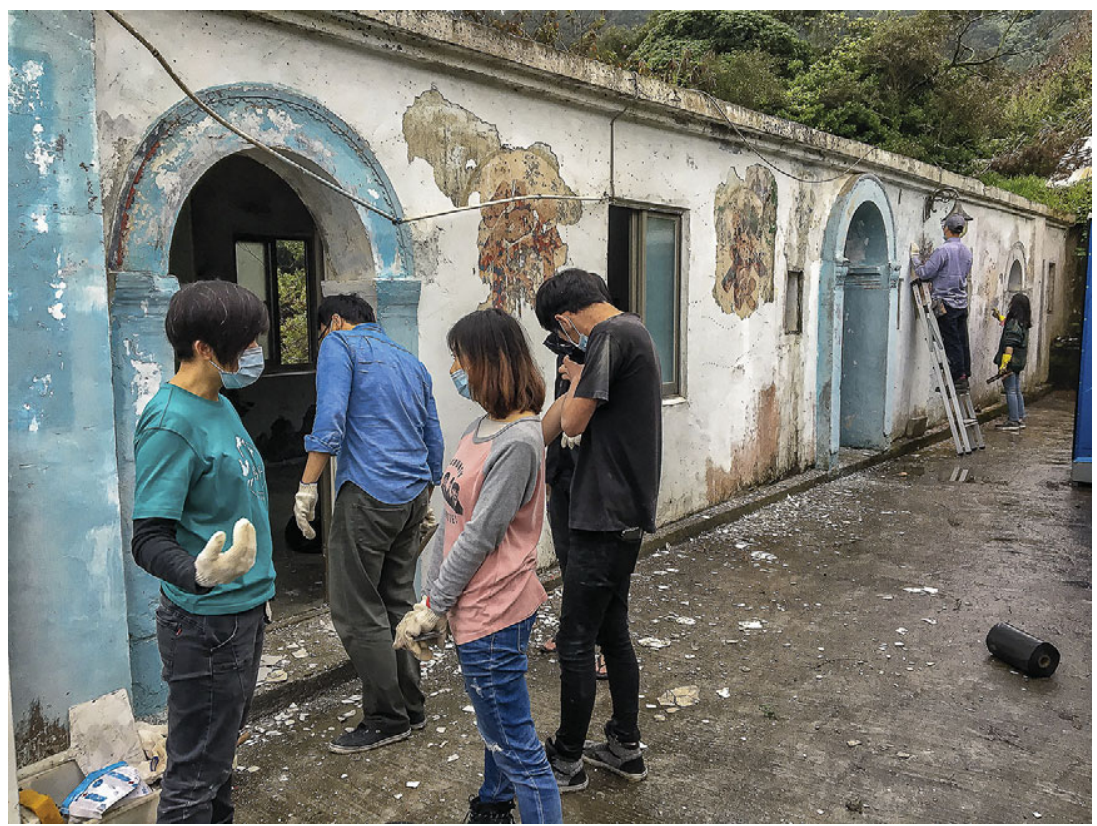

Fig. C.3 Youth Association members together cleaning up the abandoned Zhuluo Elementary School (Photo by Cai Jiaru)

the abandoned school. They themselves rehabilitated the building, which had been in disuse for fifty-three years (Figure C.3). It has become a base for them to relearn the lost way of living on the island with its marine ecology. For example, they regularly invite elders to share with them how to collect seasonal shellfish and sea weeds, and make Matsu dishes out of them; many of these practices were neglected or suppressed during the military rule.

At the end of a long conversation, I once asked Yaping what they intended to achieve now that they had found a base to work from. She responded resolutely with a clear set of goals:

We intend to learn about oceanic culture, and to understand the wartime history of Matsu. We want to redefine Matsu with respect to Taiwan and the rest of the world, rather than just returning to our ancient Fuzhou roots. We hope to open up this space, to make it a place where people across the generations can gather and learn together. 
Eventually, however, she shook her head and admitted:

To tell you the truth, I don't know what we really intend to become. All we can do is to keep exploring together with our members and the residents here. We hope someday that we can "become ourselves" (chengwei women ziji)!

I was thrilled to learn that the goal that she and the young members have set for themselves, out of this deserted school with a military history, is no longer self-stylization, as is the aim of Cao, or genealogical reconnection with ancestors, as Yang yearns for. Rather, by extending connections laterally and by cooperating with each other, they are pursuing a new ethic of belonging and living - in this new mode of being they could finally "become themselves."

In the present day, people diverge not only in their past experiences, but also in their increasingly varied individual imaginations whose scopes have been greatly enlarged. The question of how people in the twentyfirst century can come together to face the future is a very thorny issue, and one which resists a tidy summing-up. Starting from the imagining subjects and the mediating mechanisms they deploy to reach out to others is important, and indeed imperative, for us to understand the contemporary world. 